\title{
EVALUATION BY THE FELLOW IN KNEE SURGERY IN BRAZIL
}

\section{AVALIAÇÃO DO ESPECIALIZANDO EM CIRURGIA DO JOELHO DO BRASIL}

\author{
dalton Mikio Hirano Hatano ${ }^{1}$ (i), Diego Costa astur ${ }^{1}$ (i), Marcelo abdulklech Santos ${ }^{1}$ (i), Camila Cohen Kaleka ${ }^{2}$ (i), \\ MOISES COHEN ${ }^{1,2}$ (1), ALEXANDRE PEDRO NICOLINI ${ }^{1}$ [i]
}

1. Universidade Federal de São Paulo, Department of Orthopedics and Traumatology, Sports Traumatology Center (CETE), São Paulo, SP, Brazil.

2. Instituto Cohen, São Paulo, SP, Brazil.

\section{ABSTRACT}

Objective: To evaluate the fellow in knee surgery and the training offered by accredited programs in Brazil. Methods: This cross-sectional study administered a questionnaire to fellows in knee surgery. Results: Most fellows reported being assisted by the preceptor in theoretical, practical, and scientific activities. Conclusion: The training offered by accredited programs to fellows in knee surgery presented good results for their education. This study may propose educational measures for the Brazilian Society for Surgery of the Knee (SBCJ). Level of Evidence IIC, Cross-sectional study.

Keywords: Internship and Residency. Knee. Orthopedics.

\section{RESUMO}

Objetivo: Avaliar o especializando em cirurgia de joelho e o treinamento oferecido pelos serviços credenciados no Brasil. Métodos: Estudo transversal por meio de um questionário enviado para os especializados em cirurgia de joelho responderem. Resultados: A maioria dos especializandos relataram assistência por parte da preceptoria nas atividades teórica, prática e científica. Conclusão: O treinamento dos serviços credenciados oferecido para os especializandos em cirurgia de joelho apresentou bons resultados para a formação deles. O estudo pode promover medidas educacionais para a Sociedade Brasileira de Cirurgia de Joelho (SBCJ). Nível de Evidência IIC, Estudo transversal.

Descritores: Internato e Residência. Joelho. Ortopedia.

Citation: Hatano DMH, Astur DC, Santos MA, Kaleka CC, Cohen M, Nicolini AP. Evaluation by the fellow in knee surgery in Brazil. Acta Ortop Bras. [online]. 2020;28(5):221-228. Available from URL: http://www.scielo.br/aob.

\section{INTRODUCTION}

In Brazil, orthopedic training consists of three years of medical residency and approval in the examination for title license at its end, organized by the Brazilian Society of Orthopedics and Traumatology (SBOT). These are necessary steps for an orthopedist to improve within the subspecialties. Knee fellowship lasts one year and comprises an examination at the end of the residency to grant fellows, if approved, the title of specialist.

The Brazilian Society for Surgery of the Knee (SBCJ) has accredited 83 programs with an average of 134 vacancies/year for specialty training, which includes: clinical and surgical education, theoretical training, involvement in clinical trials, and doctor-patient relationship. ${ }^{1}$ Although the country literature presents studies related to medical education and training, ${ }^{2}$ those focused on orthopedics are scarce. Moreover, little is known about the profile of the candidate that chooses to specialize in knee surgery.
This cross-sectional study aims to determine the profile of fellows in knee surgery and services accredited by the SBCJ, understanding how this population's training is and whether it follows a national standard. In doing so, our results may eventually assist further educational and universal measures.

\section{MATERIALS AND METHODS}

This study was approved by the Research Ethics Committee of the Universidade Federal de São Paulo (UNIFESP).

This cross-sectional study (level of evidence IIC, according to the Oxford Classification) administered a questionnaire to fellows in knee surgery of programs accredited by the SBCJ in 2017. All fellows agreed to participate, and their data were obtained with SBCJ consent. Yet, participants' data were kept confidential. Initially, each participant was contact by email, receiving an explanation about the study and the questionnaire attached by the

All authors declare no potential conflict of interest related to this article.

The study was conducted at Universidade Federal de São Paulo, Department of Orthopedics and Traumatology, Sports Traumatology Center (CETE).

Correspondence: Dalton Mikio Hirano Hatano. Rua Assungui, 721, apartamento 45, bloco A, São Paulo, SP, Brazil, 04131-001. dalt_hatano@hotmail.com 
digital software SurveyMonkey. Three attempts were made, with an interval of two weeks between each.

When participants failed to provide a response, telephone contact would be attempted for three times. In the eventual lack of response, we would attempt to contact the fellow by letter, two times, with the questionnaire attached.
Fellows who did not answer the survey after all attempts by email, telephone, and letter and those who answered incompletely were excluded.

The questionnaire was composed of 26 questions divided into 4 blocks: fellow's personal information, training place, practical/surgical/ clinical training, and involvement in scientific projects (Figure 1)

\section{Evaluation of residency programs in knee surgery - 2017}

Name (initials):

Age:

Gender:

Place of birth (state):

Email:

1- Have you done any other fellowship before?

2- Started fellowship in knee right after residency?

Yes

Yes

3- Same place of residency and fellowship in knee?

Yes

4- Same state of residency and fellowship?

5 - Same state of your hometown and fellowship?

6- If the previous answer was negative, do you intend to return

Yes

to your city after completing fellowship?

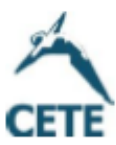

\section{Place of fellowship}

7- Is it connected to any university/faculty?

8- Is it connected to any person?

9 - Is it established in a public institution?

10- Is it established in a private institution?

11- Is it established in both private and public institutions? What percentage each?

12- How many hospitals do you attend in a typical week (in average)?

13- Do you hold a scholarship or are you paid somehow for assisting surgical procedures?

14- What is your weekly workload (in average)? Hours

15- Do you have theoretical activities? How many hours a week?

16- If the previous answer was positive, what do these theoretical activities consist of?

Class Case Discussion Seminar Cadaver lab

(service or encouraged/sponsored) Congress Articles Discussion

17- Do you consider the load of theoretical activities appropriate to take tests? How about to your knowledge?

Place/practical portion (surgeries)

18- In a typical week, in approximately how many surgeries do you participate?

Arthroplasty, Anterior Cruciate Ligament (ACL)/Posterior Cruciate Ligament (PCL) Arthroscopy,

Simple Arthroscopy/Partial Meniscectomy Meniscorraphy, Complex injuries, Other trauma/fracture,

surgeries unrelated to the knee (fractures, arthroscopies, etc.) Specify:

19- Do you actually participate in surgical procedures?

20- Does your preceptor teach during surgeries?

21- Do you believe that, at the end of the fellowship, you will be able to perform surgical procedures?

Arthroplasty, Anterior Cruciate Ligament, Posterior Cruciate Ligament

Partial meniscectomy, Complex lesions, Other surgeries Specify:

22- Does the program face financial difficulties in performing surgeries, such as lack of material, staff, etc.?

Research

23- Are you currently participating in any scientific research? How many?

24- Is the theme of your research related to knee surgery?

25- How interested are you in conducting scientific research?

Very interested Interested Indifferent Not interested

26- Do you feel that your program provides financial support/conditions for scientific activities?

\begin{tabular}{lr} 
Yes & No \\
Yes & No \\
Yes & No \\
Yes & No \\
public & private \\
Yes & No \\
\multicolumn{2}{c}{ Hours }
\end{tabular}

27- If the previous answer was negative, why?

Lack of financial conditions Lack of support (preceptor/knowledge) Other

28- Do you think that the program provides knowledge for the performance of scientific work? Such as classes, work discussion, meetings? 
Results were tabulated in the Microsoft Excel (Microsoft $\AA, U S A)$, analyzed, and interpreted. Data were presented in absolute numbers and percentages, in tables and graphs.

\section{RESULTS}

We evaluated data obtained from the questionnaires and compared them according to a division proposed by the SBCJ, which defines seven regional (São Paulo; Rio de Janeiro; South; Minas Gerais/
Espírito Santo; North; Northeast; and Midwest) for 83 accredited programs (Table 1).

Among the 134 fellows in knee surgery in 2017, 91 (68\%) were included and completed the study, and $43(32 \%)$ were excluded for not answering the survey or answering it incompletely. Table 2 shows the distribution according accredited programs location, number of fellows in the country, and number of participants in the study.

Table 1. Programs accredited by the SBCJ for fellowship training in knee surgery in Brazil.

\begin{tabular}{|c|c|}
\hline São Paulo Regional & \\
\hline 39 Programs & City \\
\hline Clínica Nunes Ortopedia Traumatologia (CNOT) & Campinas \\
\hline Centro de Estudos do Centro de Ortopedia e Reabilitação at Esporte do Hospital do Coração (CECORE) & Sao Paulo \\
\hline Centro Médico Kawano (CEMKA) & Sao Paulo \\
\hline Knee Surgery Group of the Clínica Ortopédica Tatuapé & Sao Paulo \\
\hline Clínica Pacheco & Piracicaba \\
\hline Clínica Traumato-Ortopédica Prof. Dr. Hilário Maldonado/ Associação Beneficente Hospital Universitário (ABHU) & Marilia \\
\hline Knee Group of the Complexo Hospital do Mandaqui & Sao Paulo \\
\hline Sports traumatology Group of the FMABC & Santo Andre \\
\hline Hospital Israelita Albert Einstein & São Paulo \\
\hline Sports Medicine Group of the IOT - HCFMUSP & Sao Paulo \\
\hline Hospital das Clínicas of the Faculdade de Medicina de Ribeirão Preto - USP (HC FMRP-USP) & Ribeirao Preto \\
\hline Knee Group of the Hospital das Clínicas da Faculdade de Medicina de Marília (HC-Famema) & Marilia \\
\hline Knee Group of the Hospital de Clínicas da UNICAMP (HC-UNICAMP) & Campinas \\
\hline Knee Group of the Orthopedic Trauma Service from the Hospital do Servidor Público Estadual Francismo Morato de Oliveira (HSPE-FMO) & Sao Paulo \\
\hline Knee Surgery Group of the Hospital Nipo Brasileiro & Sao Paulo \\
\hline Casa de Saúde Santa Marcelina & São Paulo \\
\hline Instituto de Ortopedia e Traumatologia (IOT) - HCFMUSP & Sao Paulo \\
\hline Núcleo de Ortopedia e Medicina Esportiva & Sorocaba \\
\hline Clinica ORTOTRAUMAESPORTE & Sao Paulo \\
\hline Ortocity Serviços Médicos & Sao Paulo \\
\hline Knee Group of the Department of Orthopedics PUC - Campinas & Campinas \\
\hline Knee Group of the Hospital Santa Casa de Misericórdia de Marilia & Marilia \\
\hline Knee Surgery Group of the Department of Orthopedics and Traumatology of the Santa Casa de Misericordia de São Paulo & Sao Paulo \\
\hline Knee Group of the DOT-EPM - UNIFESP & Sao Paulo \\
\hline Unisa & Sao Paulo \\
\hline Hospital Municipal Cármino Caricchio & Sao Paulo \\
\hline Hospital Universitário São Francisco & Bragança Paulista \\
\hline
\end{tabular}




\begin{tabular}{|c|c|}
\hline Rio de Janeiro Regional & \\
\hline 6 Programs & City \\
\hline Knee Group of the Hospital Santa Teresa & Petropolis \\
\hline Hospital Universitário Gaffrée e Guinle/Universidade Federal do Estado do Rio de Janeiro (UNIRIO) & Rio de Janeiro \\
\hline Center for Knee Surgery of the Instituto Nacional de Traumatologia e Ortopedia & Rio de Janeiro \\
\hline Knee Group of the Hospital da Polícia Militar do RJ & Rio de Janeiro \\
\hline Knee Group of the Hospital Federal dos Servidores do Estado-RJ & Rio de Janeiro \\
\hline Hospital Rios D'or & Rio de Janeiro \\
\hline \multicolumn{2}{|l|}{ South Regional (SC/ PR/ RS) } \\
\hline 14 Programs & City \\
\hline Instituto Balsini & Joinville \\
\hline Instituto de Ortopedia e Traumatologia (IOT) from Santa Catarina & Joinville \\
\hline Knee Group of the Hospital Ortopédico de Passo Fundo & Passo Fundo \\
\hline Orthopedic Trauma Service of the Hospital São Lucas of PUC-RS & Porto Alegre \\
\hline Knee Group of the Instituto de Ortopedia e Traumatologia de Passo Fundo & Passo Fundo \\
\hline Knee Group of the Santa Casa de Misericórdia de Porto Alegre & Porto Alegre \\
\hline Serviço de Ortopedia e Traumatologia Independente (SOTI) & Porto Alegre \\
\hline Clínica do Joelho de Londrina & Londrina \\
\hline Centro de Traumatologia Esportiva e Artroscopia (CTEA) & Curitiba \\
\hline Knee Group of the Hospital das Clínicas da Universidade Federal do Paraná & Curitiba \\
\hline Knee Group of the Hospital de Clinicas de Porto Alegre & Porto Alegre \\
\hline Knee Group of the Hospital Universitário Cajuru - PUC-PR & Curitiba \\
\hline Knee Group of the Hospital Universitário Evangélico de Curitiba & Curitiba \\
\hline Uniort.e Ortopedia Especializada & Londrina \\
\hline \multicolumn{2}{|l|}{ ES/MG Regional } \\
\hline 12 Programs & City \\
\hline Knee Group of the Faculdade de Ciências Médicas de Minas Gerais & Belo Horizonte \\
\hline Knee Group of the Hospital Mater Dei - BH & Belo Horizonte \\
\hline Knee Group of the Hospital das Clínicas da Universidade Federal de Minas Gerais & Belo Horizonte \\
\hline Knee Group of the Hospital de Clínicas da Universidade Federal de Uberlândia & Uberlandia \\
\hline Knee Group of the Hospital Madre Teresa & Belo Horizonte \\
\hline Hospital Ortopédico de Belo Horizonte & Uberaba \\
\hline Hospital Universitário Mário Palmério & Uberaba \\
\hline Hospital Felício Rocho & Belo Horizonte \\
\hline OrtoLife - Centro Ortopédico Avançado & Belo Horizonte \\
\hline Knee Group of the Santa Casa de Misericórdia de Belo Horizonte & Belo Horizonte \\
\hline Knee Group of the Hospital Biocor & Belo Horizonte \\
\hline Complexo Hospitalar São Franciso - Hospital Santa Lúcia (Serviço Nelson Baisi Cerqueira) & Belo Horizonte \\
\hline \multicolumn{2}{|l|}{ Midwest Regional (TO, DF, GO, MS, MT) } \\
\hline 3 Programs & City \\
\hline Knee Group of the Hospital das Forças Armadas & Brasilia \\
\hline HOME/Brazilian Olympic Committee (COB) & Brasilia \\
\hline $\begin{array}{l}\text { Knee Advanced Surgery Training of the Orthopedics and Traumatology Medical } \\
\text { Residency of the HC of the Universidade Federal de Goiás (UFG) }\end{array}$ & Goiania \\
\hline \multicolumn{2}{|l|}{ North Regional (MA, PA, AM, RN, RO, AP, AC) } \\
\hline 2 Programs & City \\
\hline Knee Group of the Hospital Adventista de Manaus & Manaus \\
\hline Knee Surgery Service of the Fundação Hospital Adriano Jorge & Manaus \\
\hline
\end{tabular}




\begin{tabular}{l|c}
\hline \multicolumn{1}{|c|}{ Table 1. Programs accredited by the SBCJ for fellowship training in knee surgery in Brazil. | Continuation } \\
\hline \multicolumn{1}{c|}{ 7 Programs } & City \\
\hline COT & Salvador \\
\hline Clínica Ortopédica de Acidentados & Recife \\
\hline Instituto de Traumatologia e Ortopedia Romeu Krause (ITORK) & Recife \\
\hline ORTOPED & Salvador \\
\hline Knee Group of the Santa Casa de Misericórdia da Bahia & Salvador \\
\hline Hospital São Rafael/Hospital Manoel Vitorino & Salvador \\
\hline Physiotherapy Center of the Obras Sociais Irmã Dulce Serviço from the Hospital Santo Antonio & Salvador \\
\hline
\end{tabular}

Table 2. Distribution by SBCJ regional and number of programs, fellows, and participants in the study.

\begin{tabular}{c|c|c|c}
\hline SBCJ Regional & Accredited Programs & 2017 Fellows & Study Participants \\
\hline São Paulo & 39 & 70 & 56 \\
\hline South & 14 & 15 & 8 \\
\hline Minas Gerais/Espírito Santo & 12 & 13 & 6 \\
\hline Northeast & 7 & 19 & 11 \\
\hline Rio de Janeiro & 6 & 11 & 6 \\
\hline Midwest & 3 & 5 & 3 \\
\hline North & 2 & 1 & 1
\end{tabular}

Fellow's mean age was 31.27 years, ranging from 27 to 39 years (Figure 2).

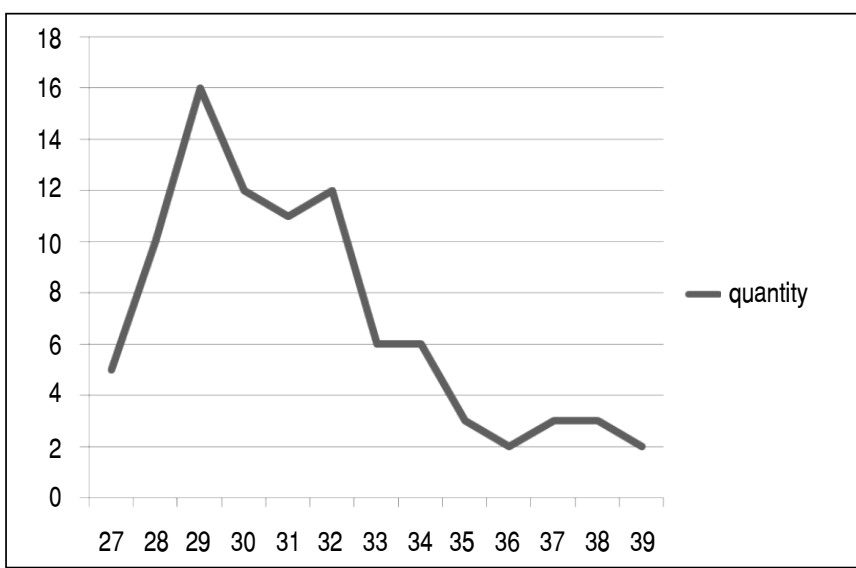

Figure 2. Number of fellows in knee surgery $\times$ age.

Only one of the 91 participants were women. All other participants were men (98.8\%). Most fellows (41\%) were born in the state of São Paulo (Table 3)

Regarding academic record, $84 \%$ of the participants started their fellowship right after finishing orthopedics residency. In total, $87 \%$ declared that knee surgery was their first fellowship. For $63 \%$, the place where they undertook orthopedics residency was not the same as the fellowship training. But $74 \%$ reported that both programs were located within the same state.

The place of residence is the same as the fellowship program for $60 \%$ of participants. For those who places differ, $80 \%$ intend to return to their hometown after completion.

Regarding accredited programs, we found that: $46 \%$ of fellows reported their programs to be connected to a university and/or faculty, among which $60 \%$ work in a public institution, $71 \%$ in a private institution, and $60 \%$ in both public and private institutions. Participants who attend both institutions reported that 20 to $60 \%$ of the activities are in public services, whereas 30 to $80 \%$ are in private services.

A total of $58 \%$ reported attending 2 to 3 hospitals weekly (Figure 3 ).

Table 3. Place of birth of 2017 fellows in knee surgery.

\begin{tabular}{|c|c|}
\hline Estados & № de especializando \\
\hline SP & 37 \\
\hline RJ & 7 \\
\hline $\mathrm{CE}$ & 6 \\
\hline$M G$ & 7 \\
\hline PA & 2 \\
\hline TO & 2 \\
\hline $\mathrm{Pl}$ & 2 \\
\hline $\mathrm{SC}$ & 1 \\
\hline PR & 5 \\
\hline $\mathrm{RN}$ & 1 \\
\hline $\mathrm{RS}$ & 5 \\
\hline PB & 1 \\
\hline MA & 2 \\
\hline RO & 2 \\
\hline ES & 2 \\
\hline $\mathrm{PE}$ & 2 \\
\hline $\mathrm{AM}$ & 1 \\
\hline $\mathrm{BA}$ & 3 \\
\hline $\mathrm{AL}$ & 3 \\
\hline
\end{tabular}




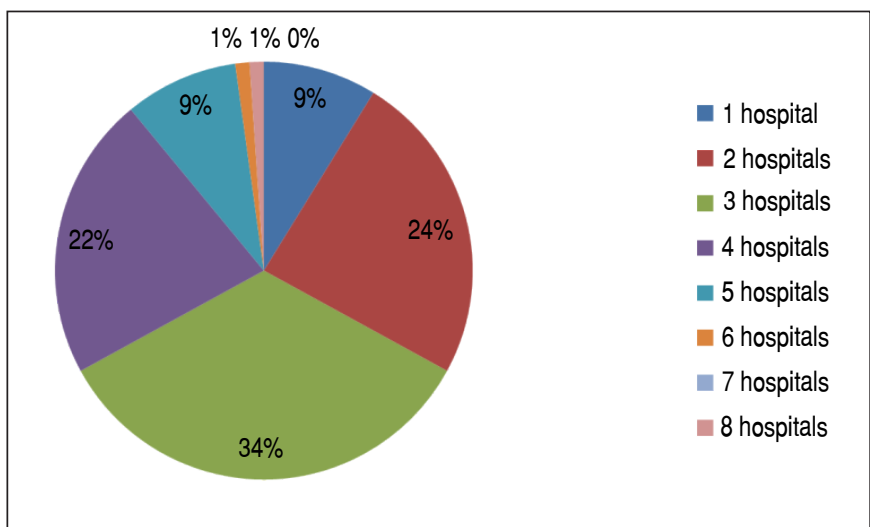

Figure 3. Number of hospitals attended by fellows in a week.

The average weekly workload was 42.07 hours (Figure 4).

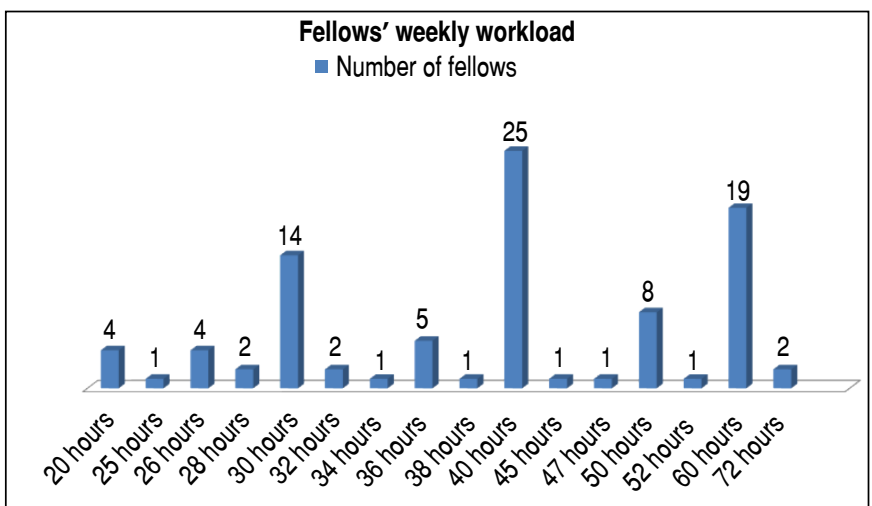

Figure 4. Fellows' workload per week.

Moreover, $89 \%$ of them receive no financial remuneration.

Regarding theoretical activities, $11 \%$ reported having no theoretical activity, and the maximum theoretical load, reported by 5 participants, was 12 hours per week (Figure 5).

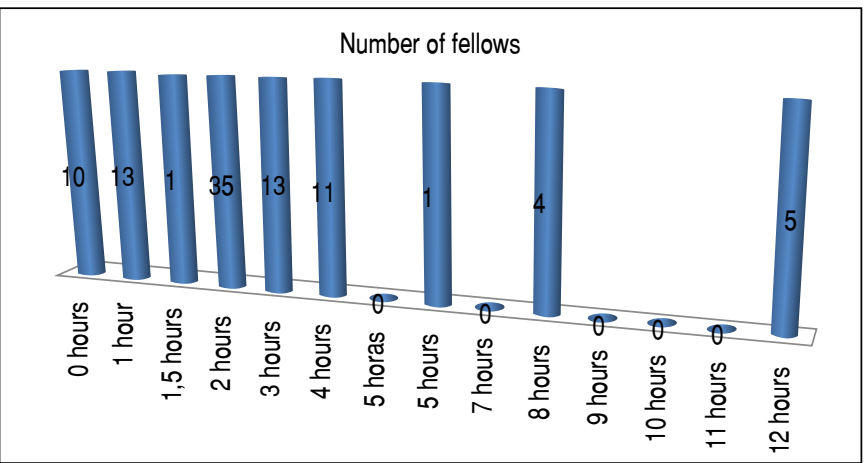

Figure 5. Weekly workload of theoretical activities.

We found $59 \%$ of fellows to consider the amount of theoretical activity adequate for both knowledge and examination. Participants distributed it as follows (Figure 6).

As for practical surgical activities, $94 \%$ of the participants reported effectively participating in surgical procedures, and 95\% reported being supported and taught by preceptors.

Regarding the type of surgical procedures in which fellows participate weekly, $64 \%$ reported participating in one to two prostheses,
$63 \%$ two to four arthroscopies, $76 \%$ two to four ACL, and $76 \%$ reported not participating in PCL. Percentages for meniscus were: $74 \%$ participate in one to three partial meniscectomy, and $39 \%$ participate in a meniscus suture repair per week, whereas $63 \%$ reported not participating in surgeries for complex lesions. Finally, $85 \%$ reported participating in other knee-related surgeries weekly, such as osteotomies, patellofemoral instability (PFI), chondral injuries, medial patellofemoral ligament reconstruction (MPFL), and $71 \%$ reported participating in one to two knee fractures (Table 4).

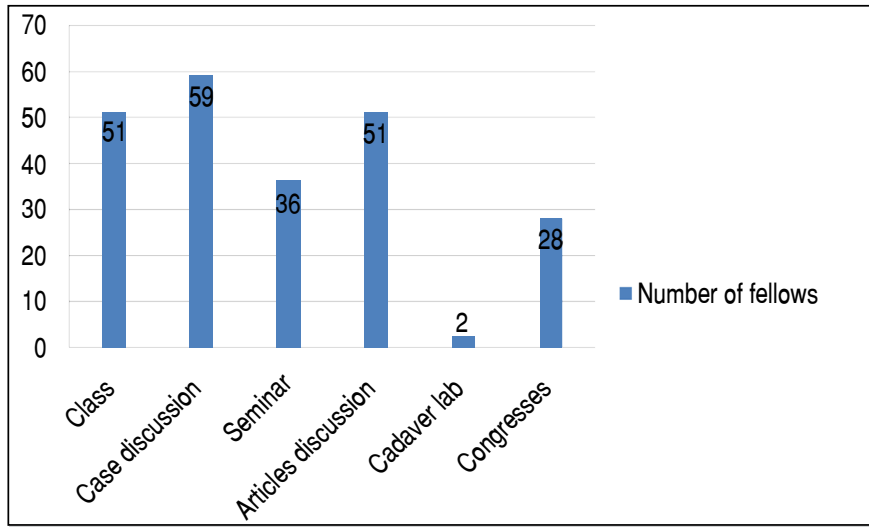

Figure 6. Number of fellows $\times$ theoretical activities.

Table 4. Number of surgical procedures performed by each fellow per week.

\begin{tabular}{c|c|c|c|c|c|c|c|c|c|c|c|c}
\hline $\begin{array}{c}\text { Types of surgical } \\
\text { procedures per } \\
\text { week X quantity }\end{array}$ & $\mathbf{0}$ & $\mathbf{1}$ & $\mathbf{2}$ & $\mathbf{3}$ & $\mathbf{4}$ & $\mathbf{5}$ & $\mathbf{6}$ & $\mathbf{7}$ & $\mathbf{8}$ & $\mathbf{1 0}$ & $\mathbf{1 3}$ & $\mathbf{1 6}$ \\
\hline Arthroplasty & 15 & 31 & 28 & 9 & 5 & 2 & 1 & 0 & 0 & 0 & 0 & 0 \\
\hline Arthroscopy & 0 & 7 & 12 & 9 & 37 & 9 & 4 & 4 & 2 & 5 & 1 & 1 \\
\hline ACL & 0 & 4 & 35 & 22 & 13 & 7 & 5 & 2 & 1 & 2 & 0 & 0 \\
\hline PCL & 70 & 21 & 0 & 0 & 0 & 0 & 0 & 0 & 0 & 0 & 0 & 0 \\
\hline Partial meniscectomy & 0 & 23 & 31 & 14 & 9 & 6 & 4 & 1 & 3 & 0 & 0 & 0 \\
\hline Meniscorraphy & 44 & 36 & 7 & 4 & 0 & 0 & 0 & 0 & 0 & 0 & 0 & 0 \\
\hline Complex lesions & 58 & 27 & 3 & 3 & 0 & 0 & 0 & 0 & 0 & 0 & 0 & 0 \\
\hline Other & 13 & 38 & 28 & 12 & 0 & 0 & 0 & 0 & 0 & 0 & 0 & 0 \\
\hline Fractures & 19 & 35 & 30 & 4 & 2 & 1 & 0 & 0 & 0 & 0 & 0 & 0 \\
\hline
\end{tabular}

We found that $64 \%$ participated in one to two prostheses per week, and $63 \%$ from two to four.

However, fellows also reported participating in surgeries in joints other than the knee joint (Figure 7).

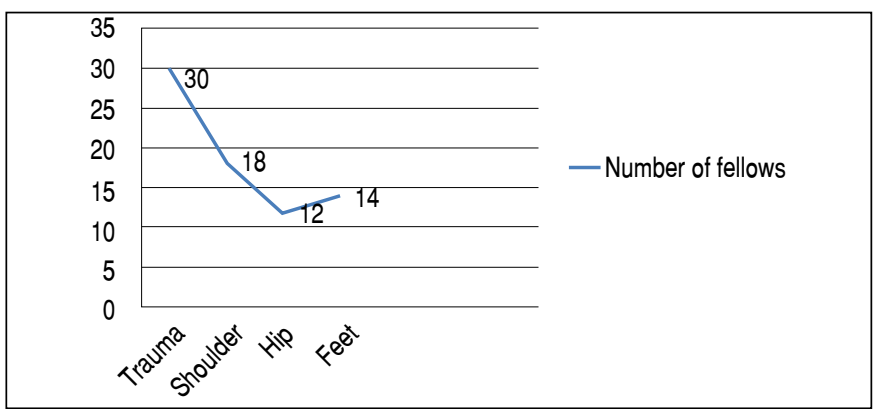

Figure 7. Surgeries in other joints performed by the fellows $\times$ number of fellows. 
By the end of the fellowship, $100 \%$ of the participants believed to be capable of performing arthroscopic ACL reconstruction and partial meniscectomy, and $61 \%$ of performing prosthesis surgery (Figure 8).

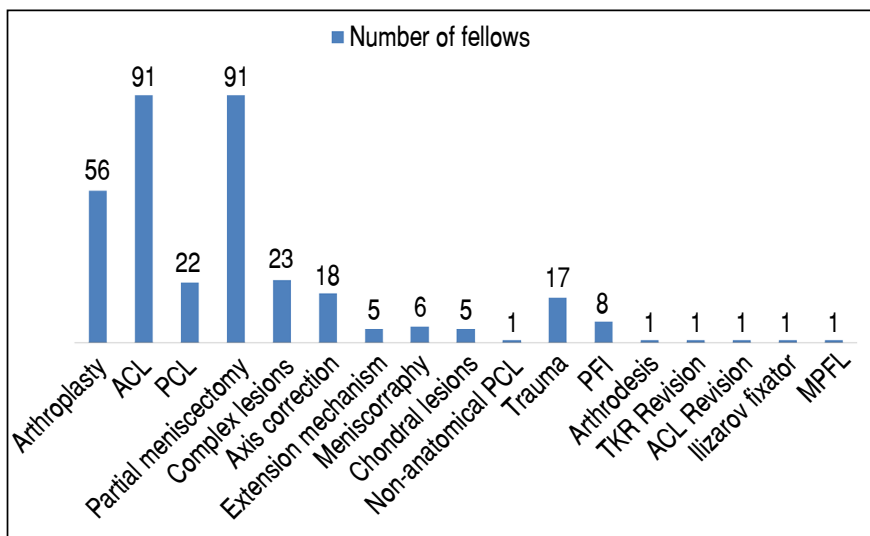

Figure 8. Surgeries fellows will be able to perform after fellowship completion.

As for financial difficulties, entailing the lack of material and team, $42 \%$ of fellows reported facing difficulties in their programs.

In total, $80 \%$ reported being involved in scientific research, among which $86 \%$ already address knee surgery as theme. Although $60 \%$ are interested in research, $28 \%$ have no support for performing it. Of these, $50 \%$ stated that the lack of support is due to having no advisor and/or knowledge.

According to $78 \%$ of the participants, their program offer support for scientific activity.

\section{DISCUSSION}

The Brazilian Society of Orthopedics and Traumatology (SBOT) is considered one of the most organized national medical specialty societies. It provides a guideline, approved by the National Medical Residency Commission by resolution No. 2/2006, for the training of residents. It also annually publishes the necessary contents and methods to their training. ${ }^{3}$

The Brazilian Society for Surgery of the Knee (SBCJ) is one of the SBOT's most traditional subspecialties, with many members in Brazil. Compared with other subspecialties, it has the largest number of applicants per vacancy for specialty training and presents numerous accredited programs throughout the country. Considering that, we deemed it would be interesting to conduct this evaluation with fellows in knee surgery.

Although there are 83 accredited programs in the country, their geographical distribution is unequal. The São Paulo regional alone has 39 programs, whereas the North regional has only two. Chaves et al. ${ }^{4}$ evaluated the national demographics of medical residency vacancies and found that the highest number of vacancies and $54.5 \%{ }^{4}$ of specialists acting in the field are within the southeast region. Such inequality could be explained by the infrastructures present in the city centers, higher salary and better job opportunities, and the improved quality of life, which favor doctors' settlement. ${ }^{4}$ However, more fellowship training programs and medical schools in poorer regions could attract and play a role in settling doctors within them. ${ }^{5}$ We found yet another discrepancy: the presence of a single female fellow in knee surgery. Women make up a larger percentage of residents in comparison to men, but men still prevail in surgical fields. ${ }^{6}$ According to Neumayer et al., ${ }^{7}$ only $15 \%$ of women end up choosing a surgical specialty. Van Heest et al. ${ }^{8}$ also showed that they represent $13 \%$ of orthopedic residents in the USA, and only $4 \%$ are members of the American Academy of Orthopedic Surgeons (AAOS).

Rohde et al. ${ }^{9}$ found some explanations of why women tend not to choose by orthopedics, such as: lack of work-life balance, high demand of physical strength, and lack of guidance in graduation. Women who opt by orthopedics often act as general orthopedists, or choose subspecialties focused in hand, pediatric, or sports.

We also analyzed preceptors' performance towards fellows. The preceptor's role is to support students in developing problem-solving strategies, besides teaching them using case discussions, classes, and surgical procedures. ${ }^{10,11,12}$ Our results indicate that fellows are satisfied with their preceptors and the theoretical teachings, esteeming SBCJ accredited programs - even though $11 \%$ of participants reported having no theoretical activities. Velho et al. $^{13}$ conducted a cross-sectional study with resident physicians in a university hospital, finding that $79.7 \%$ of them were satisfied with their preceptors' qualification and competence and $70 \%$ were unhappy or dissatisfied with the theoretical load.

Our results show that $60 \%$ of the participants work in public and private services. In Brazil, teaching hospitals reflect the issues in the public health system. The shortage of hospital beds and the lack of adequate materials and equipment compromises patient care and fellowship training in knee surgery. ${ }^{14,15}$ Conversely, the private sector complements the abovementioned scarcity, playing a key role on these professionals' training.

The most common types of knee surgeries - as ACL reconstruction, total knee replacement, and arthroscopy - often feature in fellows' routine, as well as other types of surgery, such as osteotomies, patellofemoral instability, trauma around the knee joint, extensor mechanism injuries, and chondral injuries. Interestingly, $100 \%$ of the participants believed to be capable of performing arthroscopic ACL reconstruction and partial meniscectomy by the end of fellowship, but not other procedures. An alternative to complement this range and provide a more comprehensive training would be expanding fellows' training in simulators, cadaver activities, and workshops.

Malempati et al. ${ }^{1}$ found that fellows specializing in spinal surgery also believe they need a longer time to learn certain surgeries. For Kim et al., ${ }^{16}$ a valid alternative for the training of new orthopedic surgeons would be practicing in pig knee. Martin et al. ${ }^{17}$ reported that residents improved their skills after practicing in a shoulder arthroscopy simulator. According to Aïm et al., ${ }^{18}$ virtual training improves orthopedic surgeon's technical skills, although requiring additional trials to transfer virtual training into a real operating room.

Scientific articles are the main channel for spreading medical knowledge and its advances. ${ }^{19}$ In the US, the number of scientific publications for each fellow in sports medicine increased almost 5.42 publication/year between 2016 and $2017 .{ }^{20}$ Although most of the participants in our study are involved in a scientific research, the number of publications is still not very high. Considering that, providing incentives for fellows would help increase their interest in scientific research.

Our study impose some limitations, such as the sample size, which could have comprised every 2017 fellow in knee surgery, as well as the lack of an evaluation performed by preceptors on these fellows, which could corroborate or diverge from the found results.

\section{CONCLUSION}

Most fellows in knee surgery are concentrated in the Southeast region. Our results indicate that fellows are satisfied with the theoretical, practical, and scientific activities of their programs. This study may propose educational measures for the SBCJ to standardize knee fellowship training in Brazil. 
AUTHORS' CONTRIBUTIONS: Each author contributed individually and significantly to the development of this article. DMHH: wrote the article, reviewed and prepared the research project; DCA: wrote the article, reviewed and prepared the research project; MAS: wrote the article, reviewed and prepared the research project; CCK: reviewed and prepared the research project; MC: reviewed and prepared the research project; APN: wrote the article and reviewed the text.

\section{REFERENCES}

1. Malempati H, Wadey VMR, Paquette S, Kreder HJ, Massicotte EM, Rampersaud R, et al. Spinal surgery fellowship education in Canada: evaluation of trainee and supervisor perspectives on cognitive and procedural competencies. Spine. 2013;38(1):83-91.

2. Santos RA, Snell L, Nunes MPT. Evaluation of the impact of collaborative work by teams from the National Medical Residency Committee and the Brazilian Society of Neurosurgery: retrospective and prospective study. Sao Paulo Med J. 2016;134(2):103-9.

3. Karam FC, Lopes MHI. Orthopedics: historical origin, teaching in Brazil, and methodological studies worldwide. Sci Med. 2005;15(3):172-8.

4. Chaves HL, Borges LB, Guimarães DC, Cavalcanti LPG. Vagas para residência médica no Brasil: onde estão e o que é avaliado. Rev Bras Educ Med. 2013;37(4):557-65.

5. Pinto LF, Machado MH. Médicos migrantes e a formação profissional: um retrato brasileiro. Rev Bras Educ Med. 2000;24:53-64.

6. Jesus LE. Treinar cirurgiões: hoje como sempre? Rev Col Bras Cir. 2009;36(6):529-32.

7. Neumayer L, Kaiser S, Anderson K, Barney L, Curet M, Jacobs D, et al. Perceptions of women medical students and their influence on career choice. Am J Surg. 2002;183(2):146-50.

8. van Heest $A E$, Agel J. The uneven distribution of women in orthopaedic surgery resident training programs in the United States. J Bone Joint Surg Am. 2012;94(2):e9.

9. Rohde RS, Wolf JM, Adams JE. Where are the women in orthopaedic surgery? Clin Orthop Relat Res. 2016;474(9):1950-6.

10. Botti SHO, Rego STA. Docente-clínico: o complexo papel do preceptor na residência médica. Physis. 2011;21(1):65-85.
11. Botti SHO, Rego S. Preceptor, supervisor, tutor e mentor: quais são seus papéis? Rev Bras Educ Med. 2008;32(3):363-73.

12. Botti SHO, Rego S. Processo de ensino-aprendizagem na residência médica. Rev Bras Educ Med. 2010;34(1):132-40.

13. Velho MTAC, Haeffner LB, Santos FG, Silva LC, Weinmann AGM. Residência médica em um hospital universitário: a visão dos residentes. Rev Bras Educ Med. 2012;36(3):351-7.

14. Dubeux LS, Freese E, Felisberto E. Acesso a hospitais regionais de urgência e emergência: abordagem aos usuários para avaliação do itinerário e dos obstáculos aos serviços de saúde. Physis. 2013;23(2):345-69.

15. Batista KT, Pacheco LMS, Silva LM. Avaliação dos programas de residência médica em Cirurgia Plástica no Distrito Federal. Rev. Bras. Cir. Plast. 2013;28(1):20-8.

16. Kim HJ, Kim DH, Kyung HS. Evaluation of arthroscopic training using a porcine knee model. J Orthop Surg. 2017;25(1):1-5.

17. Martin KD, Patterson DP, Cameron KL. Arthroscopic training courses improve trainee arthroscopy skills: a simulation-based prospective trial. Arthrosc. 2016;32(11):2228-32.

18. Aïm F, Lonjon G, Hannouche D, Nizard R. Effectiveness of virtual reality training in orthopaedic surgery. Arthrosc. 2016;32(1):224-32.

19. Fonseca J. Para além do fator de impacto: o artigo científico e a disseminação de conhecimento em Medicina. Rev Port Imunoalergol. 2015;23(2):67-9.

20. DeFroda SF, Shah KN, Safdar O, Mulcahey MK. Trends in research productivity ofresidents applying for orthopedic sports medicine fellowship. Phys Sportsmed. 2017;46(1):61-5. 